University of New Hampshire

University of New Hampshire Scholars' Repository

Faculty Publications

$4-1-2012$

\title{
Taking the pulse of snowmelt: in situ sensors reveal seasonal, event and diurnal patterns of nitrate and dissolved organic matter variability in an upland forest stream
}

\author{
Brian A. Pellerin \\ U.S. Geological Survey \\ John Franco Saraceno \\ U.S. Geological Survey \\ James B. Shanley \\ U.S. Geological Survey \\ Stephen D. Sebestyen \\ USDA Forest Service \\ George R. Aiken \\ U.S. Geological Survey
}

Follow this and additional works at: https://scholars.unh.edu/faculty_pubs

eernextentse for additional authors

This is an article published by Springer in Biogeochemistry in 2012, available online: https://dx.doi.org/10.1007/

s10533-011-9589-8

\section{Recommended Citation}

Pellerin, B. A., J. Saraceno, J. B. Shanley, S. Sebestyn, G. R. Aiken, W. M. Wollheim, and B. A. Bergamaschi (2011), Taking the pulse of snowmelt: In situ sensors reveal seasonal, event and diurnal patterns of nitrate and dissolved organic matter variability in an upland forest stream., Biogeochemistry. DOI 10.1007/ s10533-011-9589-8.

This Article is brought to you for free and open access by University of New Hampshire Scholars' Repository. It has been accepted for inclusion in Faculty Publications by an authorized administrator of University of New Hampshire Scholars' Repository. For more information, please contact Scholarly.Communication@unh.edu. 


\section{Authors}

Brian A. Pellerin, John Franco Saraceno, James B. Shanley, Stephen D. Sebestyen, George R. Aiken, Wilfred M. Wollheim, and Brian A. Bergamaschi 


\title{
Taking the pulse of snowmelt: in situ sensors reveal seasonal, event and diurnal patterns of nitrate and dissolved organic matter variability in an upland forest stream
}

\author{
Brian A. Pellerin · John Franco Saraceno • James B. Shanley • \\ Stephen D. Sebestyen • George R. Aiken • Wilfred M. Wollheim • \\ Brian A. Bergamaschi
}

Received: 18 May 2010/Accepted: 22 February 2011/Published online: 11 March 2011

(C) US Government 2011

\begin{abstract}
Highly resolved time series data are useful to accurately identify the timing, rate, and magnitude of solute transport in streams during hydrologically dynamic periods such as snowmelt. We used in situ optical sensors for nitrate $\left(\mathrm{NO}_{3}{ }^{-}\right)$and chromophoric dissolved organic matter fluorescence (FDOM) to measure surface water concentrations at 30 min intervals over the snowmelt period (March 21-May 13, 2009) at a 40.5 hectare forested watershed at Sleepers River, Vermont. We also collected discrete samples for laboratory absorbance and fluorescence as
\end{abstract}

Electronic supplementary material The online version of this article (doi:10.1007/s10533-011-9589-8) contains supplementary material, which is available to authorized users.

B. A. Pellerin $(\varangle)$ · J. F. Saraceno - B. A. Bergamaschi U.S. Geological Survey, Sacramento, CA 95819, USA e-mail: bpeller@usgs.gov

J. B. Shanley

U.S. Geological Survey, Montpelier, VT 05602, USA

S. D. Sebestyen

USDA Forest Service, Northern Research Station, Grand Rapids, MN 55744, USA

G. R. Aiken

U.S. Geological Survey, Boulder, CO 80303, USA

W. M. Wollheim

Water Systems Analysis Group, University of New

Hampshire, Durham, NH 03824, USA well as $\delta^{18} \mathrm{O}-\mathrm{NO}_{3}{ }^{-}$isotopes to help interpret the drivers of variable $\mathrm{NO}_{3}{ }^{-}$and FDOM concentrations measured in situ. In situ data revealed seasonal, event and diurnal patterns associated with hydrological and biogeochemical processes regulating stream $\mathrm{NO}_{3}{ }^{-}$ and FDOM concentrations. An observed decrease in $\mathrm{NO}_{3}{ }^{-}$concentrations after peak snowmelt runoff and muted response to spring rainfall was consistent with the flushing of a limited supply of $\mathrm{NO}_{3}{ }^{-}$(mainly from nitrification) from source areas in surficial soils. Stream FDOM concentrations were coupled with flow throughout the study period, suggesting a strong hydrologic control on DOM concentrations in the stream. However, higher FDOM concentrations per unit streamflow after snowmelt likely reflected a greater hydraulic connectivity of the stream to leachable DOM sources in upland soils. We also observed diurnal $\mathrm{NO}_{3}{ }^{-}$variability of $1-2 \mu \mathrm{mol} 1^{-1}$ after snowpack ablation, presumably due to in-stream uptake prior to leafout. A comparison of $\mathrm{NO}_{3}{ }^{-}$and dissolved organic carbon yields (DOC, measured by FDOM proxy) calculated from weekly discrete samples and in situ data sub-sampled daily resulted in small to moderate differences over the entire study period ( -4 to $1 \%$ for $\mathrm{NO}_{3}{ }^{-}$and -3 to $-14 \%$ for DOC), but resulted in much larger differences for daily yields ( -66 to $+27 \%$ for $\mathrm{NO}_{3}{ }^{-}$and -88 to $+47 \%$ for DOC, respectively). Despite challenges inherent in in situ sensor deployments in harsh seasonal conditions, these data provide important insights into processes controlling $\mathrm{NO}_{3}{ }^{-}$and FDOM in streams, and will be 
critical for evaluating the effects of climate change on snowmelt delivery to downstream ecosystems.

Keywords Nitrate $\cdot$ FDOM $\cdot$ Snowmelt . Forested · Diurnal

\section{Introduction}

In seasonally snow covered catchments, snowmelt often represents the single largest hydrologic event driving annual water yields (Sebestyen et al. 2009; Oczkowski et al. 2006; Boyer et al. 1997; Hornberger et al. 1994; Murdoch and Stoddard 1992) and has important implications for catchment nutrient and organic matter budgets (Sebestyen et al. 2008, 2009; Mitchell et al. 1996). Climate change is predicted to alter snowmelt runoff in upland forested catchments in the northeastern U.S. through the next century (Hayhoe et al. 2007), with changes in streamflow linked to an increase in the proportion of winter precipitation as rainfall, a decrease in snowpack depth, and earlier spring melt (Huntington et al. 2004, 2009; Hodgkins and Dudley 2006a, b). Therefore, a better understanding of snowmelt dynamics and constituent variability is needed to assess the dominant drivers and the potential effects of climate change on downstream yields of nutrients and organic matter.

The sources and magnitude of nutrient and organic matter fluxes from rivers during snowmelt are difficult to quantify given rapid changes in water flow paths, solute source areas and biogeochemical processes (Sebestyen et al. 2008; Campbell et al. 2007; Boyer et al. 2000). Traditional stream sampling approaches that collect discrete samples at daily to weekly intervals may not adequately reveal subtle shifts in sources, capture the full range of biogeochemical transformations, or allow the accurate calculation of solute budgets (Raymond and Saiers 2010; Sebestyen et al. 2008; Kirchner et al. 2004). While higher frequency water chemistry data are needed, high persample analytical costs and difficult logistics associated with field sampling are challenges to overcome as hydrologists and ecologists seek to better understand stream solute variations during hydrological events.

The application of in situ optical sensors to measure nitrate $\left(\mathrm{NO}_{3}{ }^{-}\right)$using $\mathrm{UV}$ absorbance and dissolved organic matter (DOM) using fluorescence has largely been limited to marine and coastal systems, but several recent studies have demonstrated that collecting high temporal frequency data in rivers and streams yields valuable insights into catchment processes. For example, recent studies have used in situ optical sensors in freshwater systems to assess diurnal variability in chromophoric DOM fluorescence (referred to hereafter as FDOM) and $\mathrm{NO}_{3}{ }^{-}$(Pellerin et al. 2009; Spencer et al. 2007a), storm-driven FDOM dynamics (Saraceno et al. 2009; van Verseveld et al. 2008), and nutrient uptake (Heffernan and Cohen 2010). However, no published data are available to assess the use of in situ optical sensors for capturing the rapid changes in $\mathrm{NO}_{3}{ }^{-}$and FDOM concentrations during snowmelt. In particular, the application of in situ optical sensors for $\mathrm{NO}_{3}{ }^{-}$ and FDOM in cold winter conditions with ice cover has not previously been evaluated.

The primary goal of our study was to assess the seasonal and high frequency variability of $\mathrm{NO}_{3}{ }^{-}$and FDOM and infer the primary drivers of variability during snowmelt in a forested watershed at Sleepers River, Vermont, USA. Specific objectives were to: (1) assess the timing and magnitude of $\mathrm{NO}_{3}{ }^{-}$and FDOM variability during the snowmelt period using in situ measurements, and (2) infer the hydrologic and biological controls on $\mathrm{NO}_{3}{ }^{-}$and FDOM dynamics during and after the snowmelt period from in situ and discrete data including concentration data, optical properties, and $\delta^{18} \mathrm{O}-\mathrm{NO}_{3}{ }^{-}$isotopes. FDOM represents the small fraction of the bulk DOM pool that absorbs light in the UV range $(\sim 370 \mathrm{~nm})$ and fluoresces at longer wavelengths ( $\sim 430$ to $460 \mathrm{~nm}$ ), with the magnitude of FDOM emission often proportional to the concentration of dissolved organic carbon (DOC) (Saraceno et al. 2009; Downing et al. 2009). Our results suggest that highly resolved time series are important to accurately determine $\mathrm{NO}_{3}{ }^{-}$and FDOM dynamics, and will improve our ability to measure the effects of hydrologic events such as snowmelt on constituent pulses to downstream ecosystems.

\section{Methods}

Site description

The in situ snowmelt study was conducted at the 40.5 ha Watershed 9 (W-9) in the Sleepers River Research Watershed of northeastern Vermont, a 
USGS Water, Energy and Biogeochemical Budgets (WEBB) site (Glynn et al. 2009). Sleepers River has been intensively studied as a representative northern hardwood forest that is affected by elevated nitrogen deposition (Campbell et al. 2004) and to quantify responses of stream nutrient yields to climate change (Sebestyen et al. 2009). The elevation of W-9 ranges from 519 to $686 \mathrm{~m}$, the mean annual temperature is $4.6^{\circ} \mathrm{C}$ ( -30 to $+30^{\circ} \mathrm{C}$ range), and the mean annual precipitation is $1,320 \mathrm{~mm}$. Precipitation is evenly distributed throughout the year with $20-30 \%$ accumulating as snow from December until snow melts in March or April. Streamflow and nutrient loadings are distinctively seasonal due to large snowmelt events (Shanley and Chalmers 1999; Shanley et al. 2002).

In situ monitoring and discrete sampling was conducted in a second-order tributary at the outlet of the Sleepers River W-9 (Fig. 1). On hillslopes, a dense basal till at $1-3 \mathrm{~m}$ depth is overlain by moderately to excessively well-drained inceptisols and spodosols, with histosols in wetlands (about 5\% of the catchment area) and riparian areas (Shanley et al. 2003). Stream discharge was calculated from a stage-discharge relationship, with stage measured every $5 \mathrm{~min}$ at a $120^{\circ} \mathrm{v}$-notch weir instrumented with a float-driven potentiometer. Snow water equivalent (SWE) was determined weekly in an open field (R-1A) about $1 \mathrm{~km}$ from the W-9 stream gage using an Adirondack snow sampling tube as described in Sebestyen et al. (2008). Precipitation amount was measured with a weighing bucket gauge at a meteorological station (R29) in a forest clearing adjacent to the W-9 stream gauge.

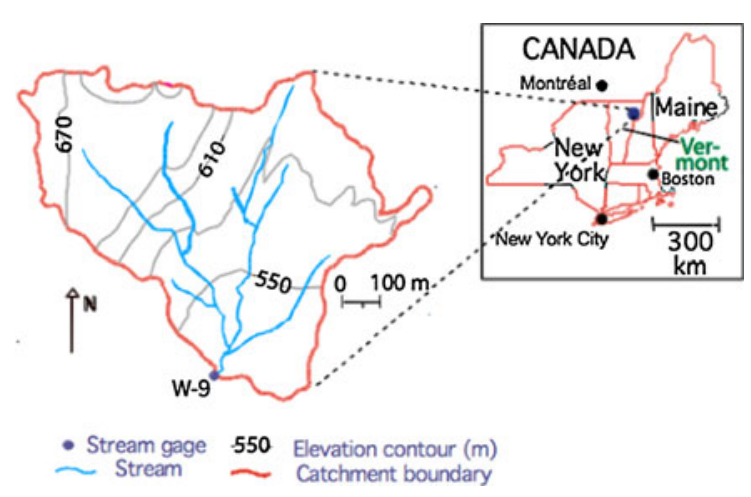

Fig. 1 Location of the Sleepers River watershed in the northeastern USA and the snowmelt study sampling location (W-9)
In situ optical measurements

In situ optical measurements of $\mathrm{NO}_{3}{ }^{-}$absorption and FDOM were made at 30-min intervals in the center of the channel just upstream of the $v$-notch weir between March 21 and May 13, 2009. The water sample was pumped to a WETLabs (Philomath, OR) flow-through WETStar FDOM fluorometer that uses a single excitation/emission pair $(370 / 460 \mathrm{~nm}$; with 10 and $120 \mathrm{~nm}$ full width at half maximum excitation/emission bandpass filters, respectively) to estimate the quantity of fluorescent, humic-like DOM similar to Peak C as reported by Coble (1996). The linear response of the sensor $\left(r^{2}>0.99\right)$ was confirmed up to $167 \mathrm{ppb}$ quinine sulfate equivalents (QSE), greater than three times the maximum values measured in this study. The FDOM fluorometer was installed for continuous measurements throughout the year and water was not filtered during the snowmelt period given the relatively low turbidity values $(<50$ FNU) throughout most of the sampling period.

The pumped sample passed from the WETStar through pre-rinsed Tygon tubing and a FiberFlo 0.2 micron cartridge filter (Mar Cor Purification, Philadelphia, PA) to an in situ ultraviolet spectrophotometer (ISUS, Satlantic, Nova Scotia, Canada) which calculates $\mathrm{NO}_{3}{ }^{-}$concentrations from absorption measurements in the spectrum from 217 to $240 \mathrm{~nm}$ (Johnson and Colletti 2002). The filter was changed midway through the study (April 14) to minimize system back pressure and reduce the likelihood of fouling. The instrument precision as reported by the manufacturer and verified in our laboratory was $\pm 0.5 \mu \mathrm{mol} 1^{-1}$ and the accuracy was $\pm 2 \mu \mathrm{mol} 1^{-1}$ with a detection limit

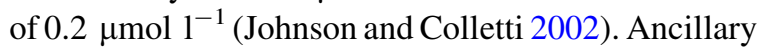
measurements of water temperature, specific conductance, and turbidity were measured every 5 min using a YSI 600 OMS equipped with YSI 6136 turbidity meter (YSI Inc, Yellow Springs, CO) deployed adjacent to the fluorometer.

\section{Data handling and processing}

In situ FDOM data were logged to a Campbell Scientific CR1000 datalogger (Campbell Scientific, Logan, UT) following a 2-min sample flush and warm up period. FDOM data were collected at $1 \mathrm{~Hz}$ for $30 \mathrm{~s}$, with the last $10 \mathrm{~s}$ of each sampling period (e.g. "burst") averaged to a single mean and standard 
deviation. The FDOM data was converted from signal voltage to units of ppb QSE (fluorescence of $1 \mathrm{ppb}$ quinine sulfate dihydrate in $0.1 \mathrm{~N} \mathrm{H}_{2} \mathrm{SO}_{4}$ ) by multiplying the blank corrected output sample voltage of the Wetstar fluorometer by an instrument specific conversion factor of $63.5 \mathrm{ppb}$ per volt supplied by the manufacturer.

ISUS $\mathrm{NO}_{3}{ }^{-}$raw absorption spectra were logged to the internal datalogger and later processed by ISUSPro version 4.0 (Satlantic, Nova Scotia, Canada). The last $10 \mathrm{~s}$ of a $30 \mathrm{~s}$ sampling period $(1 \mathrm{~Hz}$ data) was averaged to give a mean and standard of deviation $\mathrm{NO}_{3}{ }^{-}$concentration. Data were corrected for a blank water offset by a linear interpolation between pre- and post-deployment blanks ( -6.7 and -8.5 $\mu \mathrm{mol} 1^{-1}$, respectively) due to lamp degradation. We also corrected for the effect of temperature on the ISUS. While previous studies have reported a small effect of temperature in saline waters due to the presence of bromide (Sakamoto et al. 2009), our tests demonstrated a temperature offset of $0.23 \mu \mathrm{mol} 1^{-1}$ $\mathrm{N}$ per ${ }^{\circ} \mathrm{C}$ of the internal temperature of the instrument $\left(r^{2}>0.99\right.$; Supplemental Fig. S1) when operated under field conditions. The nitrate data was corrected according to this relationship using the internal temperature $\left(T_{\text {internal }},{ }^{\circ} \mathrm{C}\right)$ logged during the field deployment to calculate a temperature-corrected $\mathrm{NO}_{3}{ }^{-}$concentration using Eq. 1:

$$
\begin{aligned}
& \mathrm{NO}_{3 \text { temp_corrected }}{ }^{-}\left(\mu \mathrm{moll}^{-1}\right) \\
& \quad=\mathrm{NO}_{3 \text { raw }}{ }^{-}-\left(0.23 *\left(18.5-T_{\text {internal }}\right)\right)
\end{aligned}
$$

Several data gaps occurred due to service breaks or instrument performance, resulting in missing in situ $\mathrm{NO}_{3}{ }^{-}$and FDOM data on April 1-2 (65 measurements) and April 6-9 (147 measurements). In addition, FDOM data were not measured between March 21 and 25 (196 measurements). Missing $\mathrm{NO}_{3}{ }^{-}$data represents $8 \%$ of the 2,543 possible in situ $\mathrm{NO}_{3}{ }^{-}$ measurements in our study and data gaps were not filled for concentration data. Missing FDOM values (408 measurements total) were estimated for all gaps based on a relationship between FDOM and streamflow on the 1-3 days prior to and after each data gap $\left(r^{2}>0.96\right.$; data not shown).

\section{Discrete measurements}

Discrete stream water samples were collected manually at weekly intervals between January and May
2009, with additional samples collected during storm event periods using an ISCO autosampler at intervals of minutes to hours. In addition, we collected hourly samples over a $24 \mathrm{~h}$ period (May 12-13, 2009) to verify diurnal $\mathrm{NO}_{3}{ }^{-}$variability observed with in situ measurements. Samples were collected in 500-ml (grab) or 1-1 (autosampler) acid-washed polyethylene (PE) bottles. Samples were returned to the lab where they were kept chilled and filtered within $24 \mathrm{~h}$ into 40-ml pre-baked amber glass vials for DOC and spectral analyses $(0.7-\mu \mathrm{m}$ GF filters) or prerinsed 60-ml PE bottles for $\mathrm{NO}_{3}{ }^{-}$concentrations and $\delta^{18} \mathrm{O}-\mathrm{NO}_{3}{ }^{-}$isotopes $(0.45-\mu \mathrm{m}$ polysulfonate filters).

Samples for $\mathrm{NO}_{3}{ }^{-}$concentration were frozen and shipped to the Water Chemistry Lab of the USDA Forest Service in Grand Rapids, $\mathrm{MN}$ and were measured using suppressed conductivity detection on a Dionex DX500 ion chromatograph (Dionex, Sunnyvale, CA) with a detection limit of $1.4 \mu \mathrm{mol} 1^{-1}$. The standard deviation of triplicate check standards was $\pm 0.31 \mu \mathrm{mol} 1^{-1}$ and duplicate samples differed by less than $4 \%$. Subsets of the discrete samples were sent to the Stable Isotope Facility at the University of California in Davis to measure the natural abundance of $\delta^{18} \mathrm{O}$ in $\mathrm{NO}_{3}{ }^{-}$(i.e. $\delta^{18} \mathrm{O}-\mathrm{NO}_{3}{ }^{-}$) using the denitrifier method (Casciotti et al. 2002). The $\mathrm{NO}_{3}{ }^{-}$was converted to nitrous oxide by the bacteria Pseudomonas aureofaciens and analyzed on a Europa Integra mass spectrometer (Sercon Ltd., Cheshire, UK), with values reported in \%o relative to the VSMOW standard.

Samples for DOC and optical analysis were shipped overnight to the USGS Carbon Lab in Boulder, $\mathrm{CO}$ and measured within 1 week of sample collection. DOC concentrations were determined using an O.I. Analytical Model 700 TOC Analyzer (OI Analytical, College Station, TX) via the platinum catalyzed persulfate wet oxidation method (Aiken 1992). Ultraviolet (UV) absorbance was measured at room temperature using a quartz cell with a pathlength of $1 \mathrm{~cm}$ on a Hewlett-Packard Model 8453 photo-diode array spectrophotometer (Agilent Technologies, Inc., Santa Clara, CA). Specific UV absorbance $\left(\mathrm{SUVA}_{254}\right)$ was determined by dividing the absorbance coefficient (in units of $\mathrm{m}^{-1}$ ) determined at $\lambda=254 \mathrm{~nm}$ by DOC concentration and provides an "average" molar absorptivity of DOM (Weishaar et al. 2003) reported in units of $1 \mathrm{mg} \mathrm{C}^{-1} \mathrm{~m}^{-1}$. Spectral slope $\left(S_{290-350}\right)$, an indicator of DOM composition (Blough and Del Vecchio 2002; 
Boss and Zaneveld 2003), was calculated using a nonlinear least squares curve fitting technique on the spectral range of $290-350 \mathrm{~nm}$ as described in Saraceno et al. (2009). Fluorescence excitationemission matrices (EEMs) were measured on room temperature samples using a Horiba Jobin-Yvon Fluoromax-3 spectrofluorometer (Horiba JobinYvon, Inc., Edison, NJ). Samples were diluted with degassed organic-free DI water to a UV absorbance of 0.2 absorbance units at $254 \mathrm{~nm}$ (1 $\mathrm{cm}$ pathlength) when necessary to eliminate inner filter effects as described by Spencer et al. (2007b). EEMs were collected over an excitation range of $240-450 \mathrm{~nm}$ every $5 \mathrm{~nm}$, and an emission range of $300-600 \mathrm{~nm}$ every $2 \mathrm{~nm}$ and scans were blank subtracted, Raman normalized, and corrected for inner-filter effects (Ohno 2002). Fluorescence index (FI) was calculated on corrected EEMs as the ratio of emission intensities at 470 and $520 \mathrm{~nm}$ at an excitation wavelength of $370 \mathrm{~nm}$ (Cory and McKnight 2005).

Nitrate source apportionment

We used a two-component mixing model as described by Sebestyen et al. (2008) to estimate stream $\mathrm{NO}_{3}{ }^{-}$ contributions from direct atmospheric inputs $\left(f_{\mathrm{ATM}}\right)$ and nitrified sources flushed from near-stream or upland soils $\left(f_{\mathrm{NIT}}\right)$ using $\delta^{18} \mathrm{O}-\mathrm{NO}_{3}{ }^{-}$data. A single rainfall sample collected on March 31, 2009 had an $\delta^{18} \mathrm{O}-\mathrm{NO}_{3}{ }^{-}$value $(+82.5 \%)$ that rainfall was not significantly different ( $t$ test, $P=0.3$ ) from the average value of previous years, so we used the mean of $+86.0 \%$ ( \pm 1 standard deviation of $4.8 \%$, range $=+77.1$ to $+96.3 \%$ ) from snowmelt 2004 as the atmospheric end-member value $\left(c_{\mathrm{ATM}}\right)$. We also used the mean $\delta^{18} \mathrm{O}-\mathrm{NO}_{3}{ }^{-}$of $-2.7 \%$ for waters samples from three piezometers collected during the snowmelt event of 2004 in a near-stream area where groundwater discharges to the stream as the nitrified end-member $\left(C_{\mathrm{NIT}}\right.$; Sebestyen et al. 2008). The uncertainty of the mixing analysis was calculated using the approach of Genereux (1998), with the error $\left(W_{\mathrm{c}}\right)$ calculated using both the analytical precision of 0.8 and $6.1 \%$ o to bound a range of uncertainty values for the source apportionment. The larger error term is used as a reasonable estimate of the spatial variability of nitrified $\delta^{18} \mathrm{O}-\mathrm{NO}_{3}{ }^{-}$values across $\mathrm{W}-9$ and variability of $\delta^{18} \mathrm{O}-\mathrm{NO}_{3}{ }^{-}$values among years based on previous samples (Sebestyen 2008).
Nitrate and DOC yields

To calculate $\mathrm{NO}_{3}{ }^{-}$yields (e.g. flux/area), in situ concentrations were multiplied by the corresponding stream runoff in the 30 min interval bracketing the sample based on the time midpoint. For DOC yields, continuous in situ FDOM values were used as a proxy for DOC concentrations based on a regression using 67 discrete samples collected between March 4 and May 30, 2009 and calculated as described for $\mathrm{NO}_{3}{ }^{-}$ yields. Yields for 8 days with incomplete in situ records for $\mathrm{NO}_{3}{ }^{-}$(e.g. those with $<48$ samples day ${ }^{-1}$ ) were estimated from the relationship between water yield and $\mathrm{NO}_{3}{ }^{-}$yield for adjacent periods $\left(r^{2}<0.98\right)$. Yield estimates based on hypothetical reduced sampling frequencies were calculated by assuming a single daily in situ data point at a given time (8 a.m., 12 p.m. or 5 p.m.) multiplied by the daily stream runoff, while weekly yields were based on discrete sample concentrations (including DOC) multiplied by the total stream runoff bracketing the sample based on the day midpoint between successive samples.

\section{Results}

The maximum snowpack depth occurred in late February and snowmelt started on March 24, 2009 as indicated by increasing streamflow and decreasing SWE (Fig. 2a, b). The time from peak SWE to bare ground was approximately 50 days. The active melt period included several rain-on-snow events, including one that generated peak streamflow on April 4 (Fig. 2b). Additional spring rainfall events occurred after the snowpack melted, resulting in short duration rainfall-runoff events (Fig. 2b). Daily baseflow varied up to $28 \%$ during the early and middle phases of snowmelt, but showed little diurnal variability during baseflow after the April 22 rainfall event. Water temperatures increased from $1{ }^{\circ} \mathrm{C}$ in early April to $10^{\circ} \mathrm{C}$ in the latter part of the study (Fig. 2b) and showed diurnal variability throughout the study period.

Discrete $\mathrm{NO}_{3}{ }^{-}$concentrations incrementally increased from $13 \mu \mathrm{mol}{ }^{-1}$ during the early winter period to $20 \mu \mathrm{mol}{ }^{-1}$ at peak streamflow and rapidly decreased following peak streamflow to baseflow concentrations of $7-10 \mu \mathrm{mol} \mathrm{l}^{-1}$ (Fig. 3). Stream $\delta^{18} \mathrm{O}$ $\mathrm{NO}_{3}{ }^{-}$varied from $-3.3 \%$ prior to melt to $+10.3 \%$ just 
Fig. 2 a Daily precipitation $(\mathrm{mm})$ and weekly SWE $(\mathrm{cm})$ at during the study period and b streamflow $\left(\mathrm{mm} \mathrm{h}^{-1}\right)$ and water temperature $\left({ }^{\circ} \mathrm{C}\right)$ at out the outlet of W-9 Sleepers River Watershed

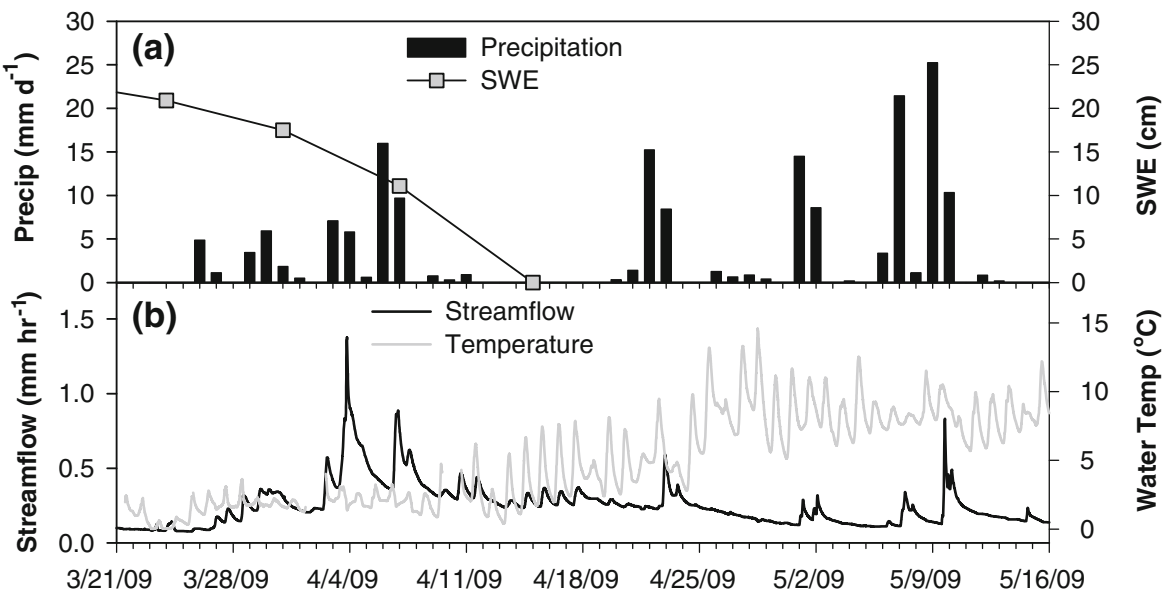

Fig. 3 Discrete $\mathrm{NO}_{3}{ }^{-}$ concentrations $\left(\mu \mathrm{mol} \mathrm{1^{-1 }}\right)$ and $\delta^{18} \mathrm{O}-\mathrm{NO}_{3}{ }^{-}(\%)$ during 2009 including the in situ instrument deployment period (shaded)

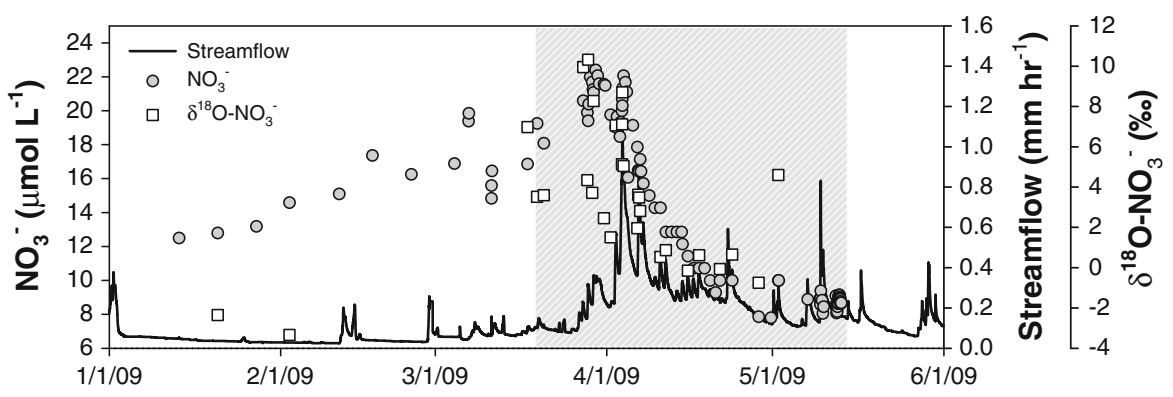

prior to peak streamflow and subsequently decreased to $\sim 0 \%$ following peak streamflow (Fig. 3). The estimated direct contribution of atmospheric $\mathrm{NO}_{3}{ }^{-}$to the stream ranges from 0 to $15 \%$ (Table 1), with the maximum percentage of atmospheric $\mathrm{NO}_{3}{ }^{-}$(March 28) occurring before peak streamflow. The uncertainty was $1 \%$ or less when $W_{\mathrm{c}}$ equaled $0.8 \%$ and $10 \%$ or less when $W_{\mathrm{c}}$ equaled $6.1 \%$ (e.g. the standard deviation of all potentially nitrified soil water and groundwater samples from W-9; Sebestyen 2008).

In situ $\mathrm{NO}_{3}{ }^{-}$concentrations were validated against lab $\mathrm{NO}_{3}{ }^{-}$concentrations $\left(r^{2}=0.97, \mathrm{NO}_{3}{ }^{-}\right.$lab $=$ $1.24 * \mathrm{NO}_{3}{ }^{-}$in situ -1.40 ; Fig. 4a: inset) for the 75 discrete samples collected between March 27 and May 13, 2009. In situ $\mathrm{NO}_{3}{ }^{-}$concentrations were typically biased lower than discrete samples (mean difference $=1.6 \mu \mathrm{mol}$ ), but were not calibrated against lab data. In situ $\mathrm{NO}_{3}{ }^{-}$concentrations had a mean standard deviation of $\pm 0.3 \mu \mathrm{mol} \mathrm{l}^{-1}$ on continuous burst samples (range $=0.1-0.6 \mu \mathrm{mol} 1^{-1}$ ), resulting in a coefficient of variation for bursts ranging from 1 to $7 \%$ (mean $=3 \%$; data not shown).
In situ $\mathrm{NO}_{3}{ }^{-}$concentrations were elevated during early snowmelt prior to peak streamflow, with a peak $\mathrm{NO}_{3}{ }^{-}$concentration of $20 \mu \mathrm{mol} 1^{-1}$ during the April 3-4 rain-on-snow event (Fig. 4a). In situ $\mathrm{NO}_{3}{ }^{-}$ concentrations subsequently declined to concentrations of $\sim 8 \mu \mathrm{mol} \mathrm{l}^{-1}$ after April 17 when the snowpack had melted. Daily maximum and minimum stream $\mathrm{NO}_{3}{ }^{-}$concentrations varied by $1-2 \mu \mathrm{mol} 1^{-1}$ when baseflow conditions prevailed through the remainder of the study and $\mathrm{NO}_{3}{ }^{-}$responses to subsequent spring rainfall events resulted in small increases in $\mathrm{NO}_{3}{ }^{-}$concentrations (Fig. 4a).

In situ FDOM concentrations were validated against laboratory-measured peak fluorescence at an excitation of $370 \mathrm{~nm}$ and emission of $460 \mathrm{~nm}$ for 61 discrete samples $\left(r^{2}=0.92, \quad P<0.001 ; \quad \mathrm{FDOM}_{\mathrm{lab}(\text { R.U. })}=\right.$ $0.0065 * \mathrm{FDOM}_{\text {in }}$ situ -0.0106$)$ collected between March 4 and May 30, 2009 (Fig. 4b: inset). Temporal patterns in FDOM concentrations were associated with streamflow, but the magnitude of the FDOM response relative to streamflow increased during the latter part of the study period. For example, the highest FDOM 
Table 1 Discrete sample $\mathrm{NO}_{3}{ }^{-}$concentrations, $\delta^{18} \mathrm{O}-\mathrm{NO}_{3}{ }^{-}(\%)$ and the estimated percentage contribution of atmospherically derived $\mathrm{NO}_{3}{ }^{-}$to streamflow in W-9

\begin{tabular}{|c|c|c|c|c|c|}
\hline $\begin{array}{l}\text { Sample } \\
\text { date }\end{array}$ & $\begin{array}{l}\text { Sample } \\
\text { time }\end{array}$ & $\begin{array}{l}\mathrm{NO}_{3}^{-} \\
\left(\mu \mathrm{mol} 1^{-1}\right)\end{array}$ & $\begin{array}{l}\delta^{18} \mathrm{O}-\mathrm{NO}_{3}{ }^{-} \\
(\% \mathrm{o})\end{array}$ & $\begin{array}{l}\text { Atmospheric } \\
\mathrm{NO}_{3}^{-}(\%)\end{array}$ & $\begin{array}{l}\text { Uncertainty } \\
(\%)\end{array}$ \\
\hline $1 / 20 / 09$ & $14: 45$ & 12.8 & -2.35 & 0 & 10 \\
\hline $2 / 2 / 09$ & $14: 45$ & 14.6 & -3.34 & 0 & 10 \\
\hline $3 / 17 / 09$ & $16: 15$ & 16.9 & 6.98 & 11 & 9 \\
\hline $3 / 19 / 09$ & $9: 26$ & 19.2 & 3.52 & 7 & 9 \\
\hline $3 / 20 / 09$ & $15: 13$ & 18.1 & 3.59 & 7 & 9 \\
\hline $3 / 27 / 09$ & $17: 50$ & 20.6 & 9.95 & 14 & 9 \\
\hline $3 / 28 / 09$ & $12: 00$ & 19.9 & 4.34 & 8 & 9 \\
\hline $3 / 28 / 09$ & $15: 00$ & 19.4 & 10.32 & 15 & 9 \\
\hline $3 / 29 / 09$ & 9:00 & 21.7 & 3.71 & 7 & 9 \\
\hline $3 / 29 / 09$ & $15: 00$ & 21.1 & 8.27 & 12 & 9 \\
\hline $3 / 31 / 09$ & $12: 25$ & 21.6 & 2.45 & 6 & 10 \\
\hline 4/1/09 & $17: 00$ & 19.8 & 1.51 & 5 & 10 \\
\hline $4 / 2 / 09$ & $15: 00$ & 19.0 & 7.06 & 11 & 9 \\
\hline 4/3/09 & $19: 10$ & 20.7 & 7.11 & 11 & 9 \\
\hline $4 / 3 / 09$ & $19: 40$ & 20.3 & 8.70 & 13 & 9 \\
\hline 4/4/09 & 1:00 & 22.1 & 5.04 & 9 & 10 \\
\hline 4/6/09 & $13: 00$ & 17.9 & 1.96 & 5 & 10 \\
\hline 4/6/09 & $17: 00$ & 16.5 & 3.62 & 7 & 10 \\
\hline 4/6/09 & 21:00 & 16.4 & 3.48 & 7 & 10 \\
\hline 4/7/09 & $1: 00$ & 17.1 & 2.82 & 6 & 10 \\
\hline $4 / 10 / 09$ & $17: 11$ & 14.3 & 0.53 & 4 & 10 \\
\hline 4/11/09 & $17: 00$ & 12.9 & 0.87 & 4 & 10 \\
\hline 4/15/09 & $17: 00$ & 11.4 & -0.15 & 3 & 10 \\
\hline 4/17/09 & $17: 00$ & 10.7 & 0.62 & 4 & 10 \\
\hline $4 / 21 / 09$ & $12: 00$ & 10.0 & -0.07 & 3 & 10 \\
\hline $4 / 23 / 09$ & $17: 00$ & 10.0 & 0.65 & 4 & 10 \\
\hline $4 / 28 / 09$ & $11: 45$ & 7.9 & -0.75 & 2 & 10 \\
\hline $5 / 2 / 09$ & $1: 28$ & 10.0 & 4.60 & 9 & 10 \\
\hline
\end{tabular}

concentrations ( $>60$ ppb QSE) were observed during a late season storm $(5 / 11 / 09)$ when peak streamflow reached only half the magnitude of peak streamflow during snowmelt (Fig. 4b).

Discrete optical measurements that are surrogates for aromatic organic compounds indicated $\mathrm{SUVA}_{254}$ (1.6-4.3 $1 \mathrm{mg}^{-1} \mathrm{~m}^{-1}$ ) and FI (1.31-1.46) were within the range of values typically reported for terrestrially derived DOM sources. The relationship of SUVA $_{254}$ and FI to streamflow exhibited two distinct regimes during the study period, with higher SUVA $_{254}$ and lower FI during spring rainfall events than during the active snowmelt period despite similar baseflow values (Fig. 5). Spectral slope $\left(S_{290-350}\right)$, another commonly used surrogate for DOM character (Blough and Del Vecchio 2002;
Boss and Zaneveld 2003) varied within a range common for higher molecular weight, terrestrially derived DOM ( -0.013 to -0.016$)$, but was not correlated with streamflow during either period $\left(r^{2}=0.004-0.008\right.$; data not shown).

In situ data revealed diurnal $\mathrm{NO}_{3}{ }^{-}$variability 1-2 $\mu \mathrm{mol}^{-1}$ during baseflow, with the highest $\mathrm{NO}_{3}{ }^{-}$concentrations in early morning and lowest in late afternoon (Fig. 6). Cross correlation analysis of in situ data showed that maxima in $\mathrm{NO}_{3}{ }^{-}$ concentrations co-varied with daily streamflow and FDOM minima and lead both parameters by approximately $2-3 \mathrm{~h}$ (Fig. 7a) during the early to middle phase of the snowmelt period $(r=-0.76$ and -0.82 , respectively, for April 13-18, 2009). Diurnal $\mathrm{NO}_{3}{ }^{-}$ variability in the period after snowmelt (e.g. April 
Fig. 4 Time series of $\mathbf{a}$ in situ $\mathrm{NO}_{3}{ }^{-}$concentrations $\left(\mu \mathrm{mol} 1^{-1}\right)$ and $\mathbf{b}$ in situ FDOM concentrations (ppb QSE) with streamflow $\left(\mathrm{mm} \mathrm{h}^{-1}\right)$ at Sleepers W-9 during the study. Insets are a the comparison of discrete and in situ $\mathrm{NO}_{3}{ }^{-}$

concentrations and $\mathbf{b}$ lab FDOM intensity (relative units) and in situ FDOM concentrations (ppb QSE)

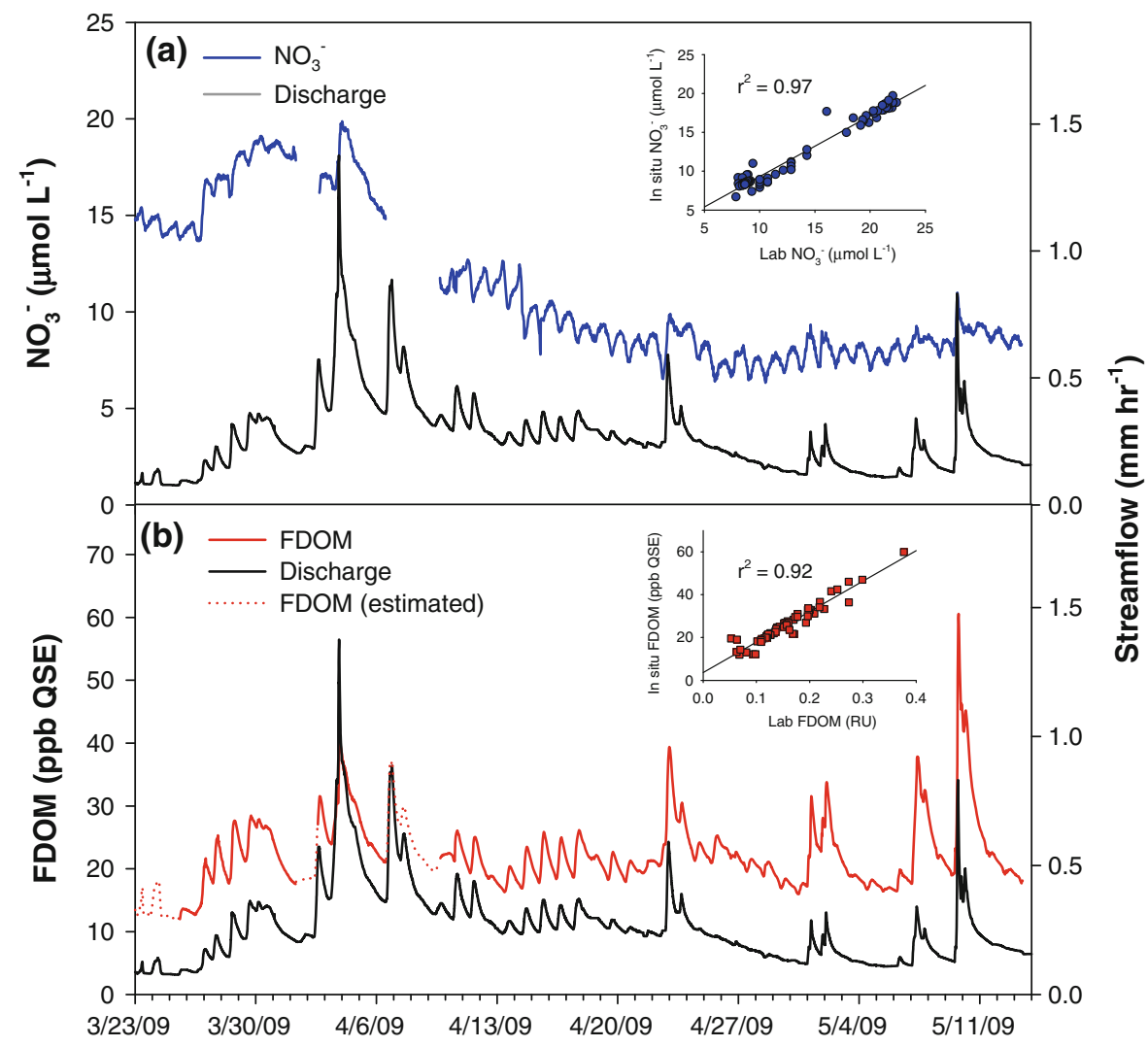

25-30; Fig. 7b) was largely independent of streamflow, but had a weak negative correlation with minima in FDOM $\left(r=-0.34,4 \mathrm{~h}\right.$ lag behind $\mathrm{NO}_{3}{ }^{-}$).

Calculated $\mathrm{NO}_{3}{ }^{-}$yield (as $\mathrm{N}$ ) based on 30-min data from the in situ measurements at W-9 was $1.04 \mathrm{mg} \mathrm{m}^{-2} \mathrm{day}^{-1}$ for the 56-day study period (Table 2). Approximately $72 \%$ of the total $\mathrm{NO}_{3}{ }^{-}-\mathrm{N}$ yield occurred during the period when snow melted (SWE $>0$ ), with $35 \%$ of the total yield occurring in the 1 week bracketing peak flow and peak instantaneous yield on April 3 at 20:00. Stream DOC yields were also calculated for the study period based on a strong proxy relationship between in situ FDOM and lab DOC concentrations in 67 samples collected between March 4 and May 30, $2009\left(r^{2}=0.87\right.$, $P<0.001 ; \quad \mathrm{DOC}_{\mathrm{lab}}=0.090 * \mathrm{FDOM}_{\mathrm{in}}$ situ +0.01$)$ with uncertainty at the 95th percentile of approximately $\pm 5 \%$ of the DOC concentration (data not shown). The calculated daily DOC yield from the 30-min FDOM data was $12.99 \mathrm{mg} \mathrm{m}^{-2}$ day $^{-1}$ (Table 2), with approximately $60 \%$ of the total DOC yield occurring during active melt and 29\% during the week bracketing peak streamflow. A comparison of yield estimates based on in situ data and lower frequency daily sub-sampling (8 a.m., 12 p.m. and 5 p.m.) or weekly discrete sampling showed differences in $\mathrm{NO}_{3}{ }^{-}$and DOC yields of -4 to +1 and -14 to $-3 \%$, respectively, for the study period (Table 2). However, a comparison of estimated daily yields from discrete weekly sampling with yields calculated from in situ data showed differences of -66 to $+27 \%$ for $\mathrm{NO}_{3}{ }^{-}$yield and -88 to $+45 \%$ for DOC during the study period (Fig. 9).

\section{Discussion}

$\mathrm{NO}_{3}{ }^{-}$and FDOM dynamics during snowmelt

High frequency in situ optical measurements revealed seasonal, event and diurnal variability in $\mathrm{NO}_{3}{ }^{-}$and FDOM concentrations during snowmelt at Sleepers River. Stream $\mathrm{NO}_{3}{ }^{-}$concentrations were highest early in the snowmelt period and decreased following peak streamflow (Fig. 4a) as observed in prior years at Sleepers River (Sebestyen et al. 2008, 2009; Ohte 


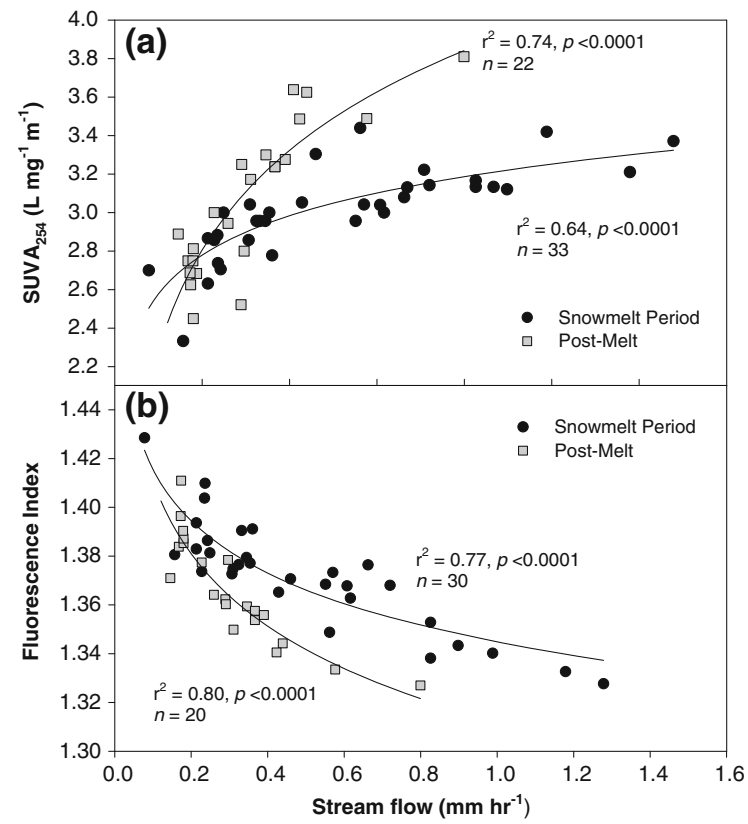

Fig. 5 Regression of DOM compositional indicators a $\operatorname{SUVA}_{254}\left(1 \mathrm{mg}^{-1} \mathrm{~m}^{-1}\right)$ and $\mathbf{b}$ fluorescence index (FI, unitless) against streamflow $\left(\mathrm{mm} \mathrm{h}^{-1}\right)$ during the active snowmelt period (March 25-April 15, 2009) and post-melt period (April 15-May 13, 2009) at Sleepers River watershed W-9

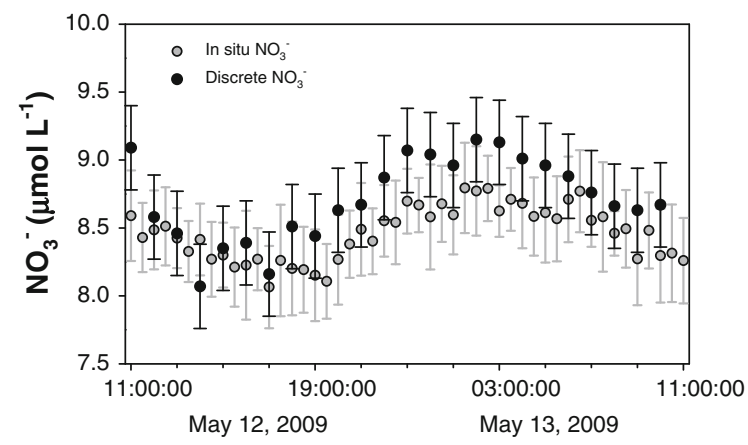

Fig. 6 Diurnal variability in hourly discrete (black squares) and in situ $\mathrm{NO}_{3}{ }^{-}$(gray circles) on May 12-13, 2009 at Sleepers River W-9. Error bars are the measured standard deviation of in situ burst samples and the standard deviation of triplicate check standards $\left( \pm 0.31 \mu \mathrm{mol}^{-1}\right)$

et al. 2004; Shanley et al. 2002). While $\mathrm{NO}_{3}{ }^{-}$ concentrations increased during baseflow prior to snowmelt, the highest in situ $\mathrm{NO}_{3}{ }^{-}$concentration during 2009 snowmelt $\left(20 \mu \mathrm{mol}^{-1}\right)$ was closely coupled temporally with peak streamflow (Fig. 4a). The dampened response of $\mathrm{NO}_{3}{ }^{-}$to subsequent spring rainfall events is consistent with the interpretation of the flushing of a finite pool of $\mathrm{NO}_{3}{ }^{-}$from soils and the snowpack to streams at Sleepers River. The early pulse in $\mathrm{NO}_{3}{ }^{-}$likely resulted from the transport of snowpack water on or near the stream channel (Sebestyen et al. 2008), while our estimate of $<15 \%$ direct input of atmospheric $\mathrm{NO}_{3}{ }^{-}$to stream runoff (Table 1) indicates soil nitrification as the dominant $\mathrm{NO}_{3}{ }^{-}$source during the study.

In contrast to $\mathrm{NO}_{3}{ }^{-}$, changes in FDOM concentrations were tightly coupled temporally with changes in streamflow throughout the entire study period and were consistent with a transport limitation of DOC rather than a source limitation at Sleepers River (Sebestyen et al. 2008). For example, peak FDOM concentrations lagged peak streamflow by less than 60 min for both the April 3 peak snowmelt event and $3.5 \mathrm{~cm}$ rainfall event on May 9-10. This tight coupling is consistent with previous studies that have shown DOC concentrations to be strongly correlated with quickflow along surficial flow paths at Sleepers River (Sebestyen et al. 2008) and is indicative of DOC production occurring along organic-rich flow paths in upland and riparian soils (Doctor et al. 2008; McGlynn et al. 1999).

While FDOM dynamics were coupled with streamflow, our high frequency data revealed a counter-clockwise hysteresis relationship between streamflow and FDOM concentration during events (Fig. 8). We hypothesize that the FDOM-discharge hysteresis observed in our study is indicative of the delayed contribution of surface and shallow subsurface flow paths on the hillslope that have higher DOC concentrations than the stream (Sebestyen et al. 2008; McGlynn et al. 1999). Inamdar et al. (2006) also reported DOC peaks lagging peak discharge in a forested watershed in New York and attributed the pattern to the delayed transport of DOC from valleybottom riparian areas. Previous work has shown a counter-clockwise hysteresis between hillslope groundwater levels and streamflow at Sleepers River (Kendall et al. 1999), supporting our hypothesis that hillslope water during the falling limb was the dominant source of higher DOC concentrations during rainfall and snowmelt.

In contrast to our study, Raymond and Saiers (2010) found in a study of 30 forested watersheds in the Northeastern U.S. that all sites followed a clockwise DOC-discharge hysteresis. Why a similar 


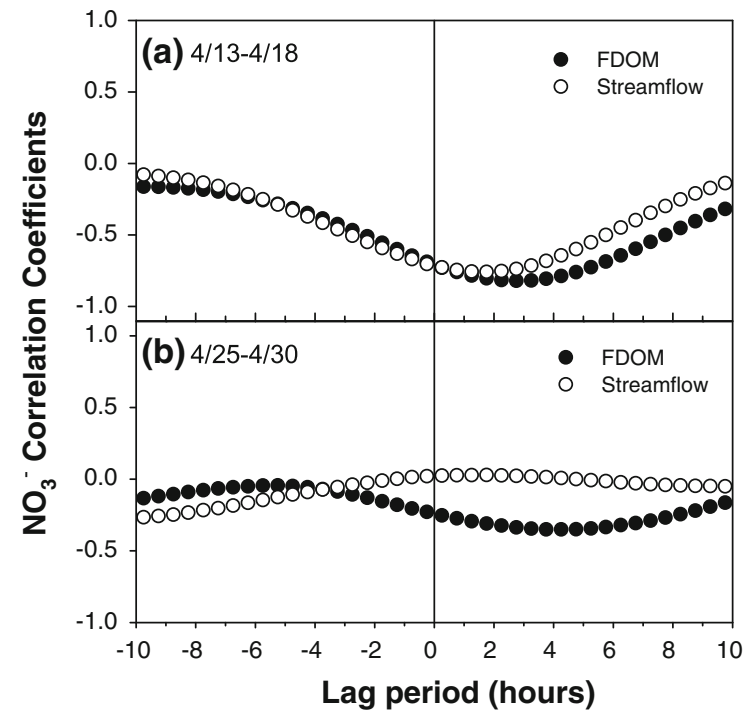

Fig. 7 Lag plot for cross correlation between in situ $\mathrm{NO}_{3}{ }^{-}$ concentration $\left(\mu \mathrm{mol} 1^{-1}\right.$ ) and FDOM (ppb QSE) or streamflow $\left(\mathrm{mm} \mathrm{h}^{-1}\right)$ during 5 day periods: a April 13-18, 2009 and b April 25-30, 2009

hillslope response is not observed in the sites studied by Raymond and Saiers (2010) is not clear, but a clockwise DOC-discharge hysteresis pattern has previously been ascribed to a temporary depletion of the terrestrial DOC supply flushed prior to peak flow (Ågren et al. 2008; Boyer et al. 2000; Hornberger et al. 1994) or changes in the connectivity of riparian and hillslope flowpaths to the stream channel (Pacific et al. 2010; McGlynn and McDonnell 2003). Sleepers River W-9 has a slightly higher percentage (5\%) of wetlands than the sites studied by Raymond and Saiers $(<1 \%)$, and previous studies have shown that stream DOC concentrations are often correlated with wetland abundance (Raymond and Hopkinson 2003; Eckhardt and Moore 1990; Mulholland and

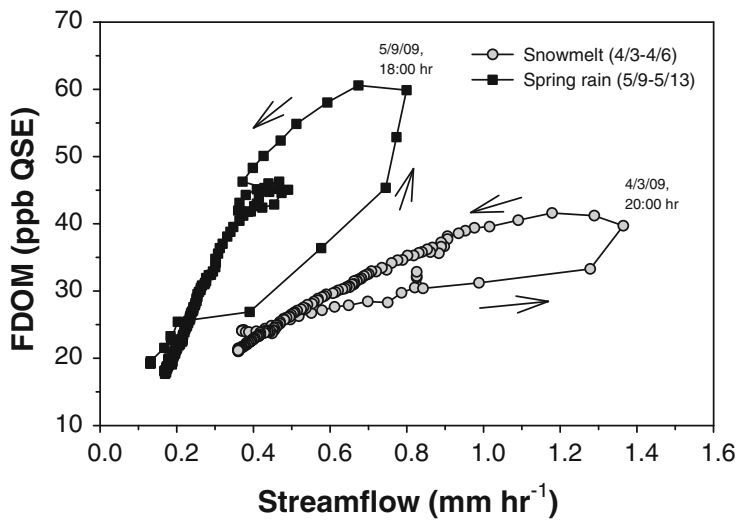

Fig. 8 Relationship between in situ FDOM and streamflow during peak snowmelt (April 3-6, 2009) and a spring rainfall event (May 9-13, 2009) at Sleepers River W-9

Kuenzler 1979). However, Kendall et al. (1999) found that riparian groundwater levels at Sleepers River increased on the rising limb of the stream hydrograph, suggesting that a riparian DOC source would have resulted in a clockwise FDOM-discharge hysteresis in our study. Alternatively, the upslope extension of the riparian saturated zone at Sleepers River-resulting in the downslope flux of hillslope water along shallow flow paths (McGlynn et al. 1999)—-may be indicative of the importance of riparian wetlands for facilitating DOM transport by hydrologically connecting streams to organic-rich flowpaths in upslope areas.

In situ fluorometers also show that the magnitude of FDOM response to streamflow during individual events varies during the study period (Fig. 4b). The observed FDOM-streamflow hysteresis during peak snowmelt (April 3-6) and a large spring rainfall event (May 9-13) indicated a steeper FDOM response during the spring rain event on both the rising and

Table 2 Daily yields of $\mathrm{NO}_{3}^{-}$and DOC $\left(\mathrm{mg} \mathrm{m}^{-2}\right.$ day $\left.{ }^{-1}\right)$ calculated from in situ optical measurements, sub-sampled daily concentrations and discrete weekly samples over a 56-day period (March 18-May 12, 2009)

\begin{tabular}{lllll}
\hline Sample frequency & $\begin{array}{l}\mathrm{NO}_{3}^{-} \text {yield } \\
\left(\mathrm{mg} \mathrm{N} \mathrm{m}^{-2} \mathrm{day}^{-1}\right)\end{array}$ & $\begin{array}{l}\mathrm{NO}_{3}^{-} \\
\text {difference }(\%)\end{array}$ & $\begin{array}{l}\text { DOC yield } \\
\left(\mathrm{mg} \mathrm{C} \mathrm{m}^{-2} \text { day }^{-1}\right)\end{array}$ & $\begin{array}{l}\text { DOC } \\
\text { difference }(\%)\end{array}$ \\
\hline 30 min data & 1.04 & na & 12.99 & na \\
Daily-8 a.m. & 1.04 & 1 & 11.93 & -8 \\
Daily-12 p.m. & 1.01 & -2 & 11.64 & -10 \\
Daily-5 p.m. & 0.99 & -4 & 12.58 & -3 \\
Weekly & 1.01 & -2 & 11.22 & -14 \\
\hline
\end{tabular}

Percent differences are calculated relative to the 30-min in situ data 


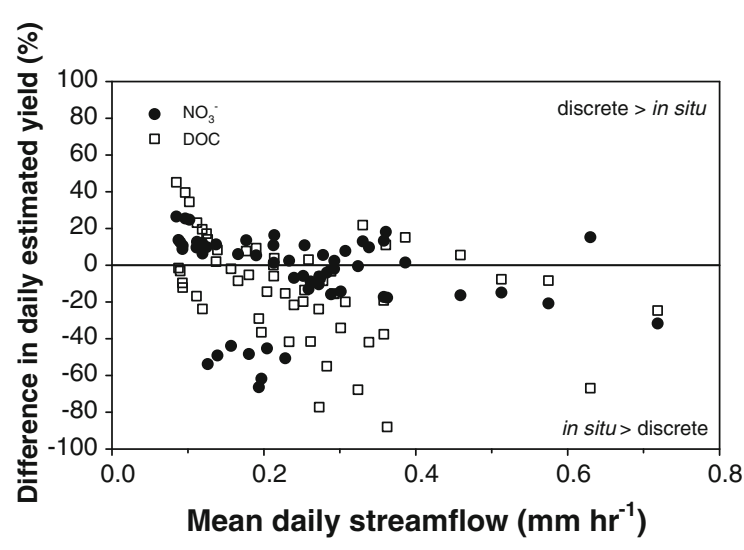

Fig. 9 Percentage difference between daily yields calculated from in situ data (48 samples per day) and discrete samples (1 sample per week) relative to mean daily streamflow $\left(\mathrm{mm} \mathrm{h}^{-1}\right)$ from March 21 to May 13, 2009 at Sleepers River W-9. Positive percentages indicate an overestimate in discrete yields relative to in situ yields, while negative percentages indicate an underestimate relative to in situ yields

falling limb of the hydrograph (Fig. 8). Discrete optical measurements showed that DOM exported after snowmelt also had a higher $\mathrm{SUVA}_{254}$ and lower FI at an equivalent streamflow than DOM exported during snowpack melting (i.e. maximum to zero SWE; Fig. 5). While these patterns indicate a general shift toward more aromatic DOM with higher streamflow as reported previously by Schuster et al. (2008), we hypothesize that compositional differences between early and late in the study period reflect greater connectivity to organic matter-rich shallow flowpaths in upland soils during spring events with high antecedent soil moisture (Sebestyen et al. 2008). However, changes in DOM production and leaching with increasing temperatures deserve further attention as a possible driver of seasonal differences (Raymond and Saiers 2010).

\section{Diurnal $\mathrm{NO}_{3}{ }^{-}$Variability}

While several recent studies have observed diurnal $\mathrm{NO}_{3}{ }^{-}$and FDOM variability in rivers and streams (Pellerin et al. 2009; Saraceno et al. 2009; Roberts and Mulholland 2007; Spencer et al. 2007a; Mulholland et al. 2006; Harrison et al. 2005; Scholefield et al. 2005), few studies in freshwater systems have collected concentration data at sufficient resolution to evaluate diurnal $\mathrm{NO}_{3}{ }^{-}$and FDOM dynamics during an extended event such as snowmelt. Our in situ measurements revealed diurnal $\mathrm{NO}_{3}{ }^{-}$variability of 1-2 $\mu \mathrm{mol}^{-1}$ during baseflow periods throughout study (Fig. 4a). During the early to middle stages of melt, diurnal $\mathrm{NO}_{3}{ }^{-}$variability occurred in concert with diurnal streamflow and FDOM concentrations with daily $\mathrm{NO}_{3}{ }^{-}$minima occurring $2-3 \mathrm{~h}$ before the maximum daily FDOM and streamflow (Fig. 7). While the inverse relationship between streamflow and $\mathrm{NO}_{3}{ }^{-}$concentrations in our study suggests a hydrologic control on diurnal variability, diurnal $\mathrm{NO}_{3}{ }^{-}$variability continued at approximately the same amplitude after the diurnal runoff pattern ceased and was largely independent of discharge and FDOM concentrations (Fig. 7b).

Diurnal $\mathrm{NO}_{3}{ }^{-}$variability in streams has been attributed to a number of processes including biological assimilation, nitrification and denitrification as well as hydrologic drivers (Heffernan and Cohen 2010; Pellerin et al. 2009; Mulholland et al. 2006; Harrison et al. 2005). We hypothesize that the inverse diurnal relationship of $\mathrm{NO}_{3}{ }^{-}$concentrations with discharge and FDOM during the active melt period (Fig. 7a) was largely influenced by hydrology, as the daily melt pulses diluted baseflow contributions of soil $\mathrm{NO}_{3}{ }^{-}$from the previous growing season and recent production under the snowpack. The initial snowmelt pulses also resulted in a greater relative contribution of atmospheric $\mathrm{NO}_{3}{ }^{-}$as shown by elevated $\delta^{18} \mathrm{O}-\mathrm{NO}_{3}{ }^{-}$values and consistent with past findings at W-9 of higher direct snowpack contributions with daily peak snowmelt discharge (Sebestyen et al. 2008; Ohte et al. 2004).

Biological transformations are expected to be less important controls on stream $\mathrm{NO}_{3}{ }^{-}$concentrations during high flow periods such as snowmelt when large volumes of water and solutes are rapidly transported through stream reaches (Mulholland 2004; Fisher et al. 1998). However, the diurnal $\mathrm{NO}_{3}{ }^{-}$variability observed after snowmelt suggests that in-stream biological processes may be driving $\mathrm{NO}_{3}{ }^{-}$concentrations despite water temperatures less than $15^{\circ} \mathrm{C}$ (Fig. 2). Other studies in forested watersheds have reported high diurnal $\mathrm{NO}_{3}{ }^{-}$uptake in streams during spring due in part to high light availability fueling autotrophic production before leaf out (Rusjan and Mikoš 2010; Mulholland et al. 2006, 2009; Roberts and Mulholland 2007). While stream $\mathrm{NO}_{3}{ }^{-}$uptake rates were not measured as part of our study, we can estimate the maximum daily stream 
$\mathrm{NO}_{3}{ }^{-}$uptake velocities $\left(v_{\mathrm{f}}\right.$; Stream Solute Workshop 1990) necessary for autotrophic assimilation to explain the observed diurnal variability during the post-melt period. The $v_{\mathrm{f}}$ value is a commonly used metric of nutrient spiraling calculated from the daily maximum $\left(C_{\max }\right)$ and minimum $\left(C_{\min }\right) \mathrm{NO}_{3}{ }^{-}$concentrations and the daily hydraulic load (HL) as described in Wollheim et al. (2006). Daily $\mathrm{NO}_{3}{ }^{-}$ drawdown in our study could be described by median $v_{\mathrm{f}}$ values over the entire study period of $1.1 \mathrm{~mm}$ $\mathrm{min}^{-1}$ (25th and 75th percentiles $=0.8-1.8 \mathrm{~mm}$ $\min ^{-1}$; data not shown), comparable to a median $v_{\mathrm{f}}$ value of $1.4 \mathrm{~mm} \mathrm{~min}^{-1}$ calculated from a synthesis of stream $\mathrm{NO}_{3}{ }^{-}$experiments in a range of second order streams by Ensign and Doyle (2006) (25th and 75th percentiles $=0.4-3.3 \mathrm{~mm} \mathrm{~min}^{-1}$ ).

$\mathrm{NO}_{3}{ }^{-}$addition experiments or concurrent in situ dissolved oxygen measurements (e.g. Heffernan and Cohen 2010) would be needed to confirm gross primary production and uptake at $\mathrm{W}-9$ during the snowmelt period, particularly given the uncertainties inherent in measuring the small range of diurnal variability $\left(1-2 \mu \mathrm{mol} \mathrm{l}^{-1}\right)$ with optical sensors in cold conditions. However, our estimates of $v_{f}$ support uptake by in-stream autotrophs as a possible driver of diurnal $\mathrm{NO}_{3}{ }^{-}$variability between snowmelt and leaf out. The relative importance of biological processes during active snowmelt deserves further attention, particularly given the consistent magnitude and timing of baseflow $\mathrm{NO}_{3}{ }^{-}$variability during both the melt and post-melt period in our study. While the observed differences are small relative to the magnitude of diurnal $\mathrm{NO}_{3}{ }^{-}$variability reported in agriculturally influenced rivers (Pellerin et al. 2009; Harrison et al. 2005), subtle shifts in in-stream retention during the snowmelt period may have important implications for understanding stream nitrogen dynamics and predicted responses to climate change.

Snowmelt $\mathrm{NO}_{3}{ }^{-}$and DOC yields

Previous studies have highlighted the potential error in calculating constituent yields with temporal sampling that does not adequately capture the variability in hydrology or constituent transport (Raymond and Saiers 2010; Sebestyen et al. 2008). For example, Raymond and Saiers (2010) found that $60 \%$ of the DOC flux from forested watersheds in the eastern U.S. occurs during the rising limb of storm events and $26 \%$ of the DOC flux on the declining limb. In situ $\mathrm{NO}_{3}{ }^{-}$ concentrations allowed for the estimation of $\mathrm{NO}_{3}{ }^{-}$ yields with high accuracy over the 56-day snowmelt study (e.g. $n=2,330$ measurements) at Sleepers River. Similarly, a strong correlation between 30-min in situ FDOM data and lab DOC concentrations $\left(r^{2}=0.87, P<0.001\right)$ allowed for the estimate of high resolution DOC fluxes via optical proxy measurements. Average $\mathrm{NO}_{3}{ }^{-}$(as $\mathrm{N}$ ) and DOC yields in our study were 1.04 and $12.99 \mathrm{mg} \mathrm{m}^{-2}$ day $^{-1}$ (Table 2), with approximately one-third of the yield occurring during the 7-day period bracketing peak streamflow during snowmelt on April 3-4. Sebestyen et al. (2008) reported mean annual yields for $\mathrm{NO}_{3}{ }^{-}$ and DOC of $158 \pm 48 \mathrm{mg} \mathrm{N} \mathrm{m}$ year $^{-1}$ and $1309 \pm 362 \mathrm{mg} \mathrm{C} \mathrm{m}^{-2}$ year $^{-1}$ respectively, for W-9 between 1992 and 2003, indicating that the 56-day study period would have accounted for about $37 \%$ of $\mathrm{NO}_{3}{ }^{-}$and $56 \%$ of DOC flux in an average year.

A comparison of yield estimates based on continuous in situ data and weekly sampling in our study revealed relatively small to moderate differences in yields for the study period $\left(-2\right.$ and $-14 \%$ for $\mathrm{NO}_{3}{ }^{-}$ and DOC, respectively; Table 2). Calculated yields based on hypothetical once per day sampling at different times (8 a.m., 12 p.m., or 5 p.m.) also showed a relatively small to moderate sampling bias with estimated yields of -4 to $+1 \%$ for $\mathrm{NO}_{3}{ }^{-}$and -10 to $-3 \%$ for DOC relative to $30-\mathrm{min}$ in situ data (Table 2). The small error in $\mathrm{NO}_{3}{ }^{-}$yields associated with lower frequency sampling is likely due to the small range in $\mathrm{NO}_{3}^{-}$concentrations and relative insensitivity of $\mathrm{NO}_{3}{ }^{-}$concentrations to streamflow following peak snowmelt (Fig. 4a). In contrast, error as high as $-14 \%$ for DOC yields occurs at the same weekly sampling frequency with low percent $\mathrm{NO}_{3}{ }^{-}$ error, consistent with differences in the dominant drivers and availability of $\mathrm{NO}_{3}{ }^{-}$(source limited) and DOC concentrations (transport limited) in this study.

The relatively low bias observed for $\mathrm{NO}_{3}{ }^{-}$and DOC yields in our study using sampling frequencies varying from 48 samples per day to 1 sample per week suggests that traditional discrete sampling approaches may be appropriate for yield calculations in some systems and during certain times of year. However, daily fluxes used to calculate these values indicate day to day variability in yield estimates by the two approaches (weekly discrete versus in situ) of 
-66 to $+27 \%$ for $\mathrm{NO}_{3}{ }^{-}$and -88 to $+45 \%$ for $\mathrm{DOC}$ (Fig. 9). In particular, DOC yields calculated from discrete samples resulted in large underestimates ( -30 to $-88 \%)$ during days with moderate mean daily streamflow due to rainfall (Fig. 9). Therefore, caution should be exercised when interpreting yields for the entire study period, particularly for constituents such as DOC that are closely coupled with runoff.

\section{Conclusions}

Our study demonstrates the utility of in situ optical sensors for measuring changes $\mathrm{NO}_{3}{ }^{-}$and DOM in freshwater systems despite challenges associated with winter and spring deployments (e.g. ice cover, limited solar power, and high flow conditions). Our data revealed seasonal, event and diurnal patterns in $\mathrm{NO}_{3}{ }^{-}$ and FDOM concentrations during the snowmelt period at Sleeper River that were consistent with hydrological and biogeochemical processes regulating the variation of stream concentrations. An early peak in $\mathrm{NO}_{3}{ }^{-}$concentrations and subsequent decrease after peak streamflow suggests the flushing of a finite source of $\mathrm{NO}_{3}{ }^{-}$(atmospheric and soil-derived) from the landscape to the stream, while the relationship between FDOM concentrations and streamflow throughout the entire study period suggests a tight coupling between the lateral transport along shallow hillslope flow paths to stream concentrations.

Our dataset also provides two examples (FDOMdischarge hysteresis and diurnal $\mathrm{NO}_{3}{ }^{-}$variability) where high frequency optical data revealed subtle shifts over time-scales that are often difficult to measure with discrete sampling approaches. Given the inherent difficulties in traditional approaches for measuring and modeling DOM-discharge hysteresis (Raymond and Saiers 2010; Butturini et al. 2008), high resolution in situ data ensure data across the hydrograph and new opportunities for model validation for a range of hydrologic events. Similarly, continuous data allowed for a more comprehensive view of the magnitude and patterns in $\mathrm{NO}_{3}{ }^{-}$ variability, as well as new hypotheses about the relative importance of hydrologic and in-stream biological drivers of $\mathrm{NO}_{3}{ }^{-}$dynamics during the snowmelt period.

Climate projections for the northeastern U.S. predict increases in winter precipitation and the intensity of extreme events (Hayhoe et al. 2007), likely affecting DOC and $\mathrm{NO}_{3}{ }^{-}$yields by altering the amount of lateral flow along surficial flow paths and biogeochemical cycling (Campbell et al. 2009; Sebestyen et al. 2009). Understanding these processes and the impacts of other episodic events such as ice storms (Judd et al. 2007; Houlton et al. 2003) and insect defoliation (Riscassi and Scanlon 2009; Lewis and Likens 2007) on stream $\mathrm{NO}_{3}{ }^{-}$and FDOM concentrations will benefit from data that accurately capture rapid responses and subtle shifts in biogeochemical cycles. In situ optical sensors coupled with discrete measurements will likely yield significant new insights into these processes and will consequently improve our ability to evaluate the effects of climate change on constituent pulse to downstream ecosystems.

Acknowledgments We thank Jon Denner, Ann Chalmers and Stewart Clark for field sampling and Kenna Butler for lab optical analyses. We also thank Bryan Downing, Dan Doctor, Mark Green and two anonymous reviewers for helpful discussions and comments on an earlier version of the manuscript. This work was funded by a USDA Forest Service Northeastern States Research Cooperative competitive grant, the USGS Climate Effects Network, the USGS Hydrologic Networks and Analysis Program, and the Northern Research Station of the USDA Forest Service. The use of brand names in this manuscript is for identification purposes only and does not imply endorsement by the US Geological Survey.

\section{References}

Ågren A, Buffam I, Berggren M, Bishop K, Jansson M, Laudon H (2008) Dissolved organic carbon characteristics in boreal streams in a forest-wetland gradient during the transition between winter and summer. J Geophys Res 113:G03031. doi:10.1029/2007JG000674

Aiken GR (1992) Chloride interference in the analysis of dissolved organic carbon by the wet oxidation method. Environ Sci Technol 26:2435-2439

Blough NV, Del Vecchio R (2002) Chromophoric DOM in the coastal environment. In: Hansell D, Carlson C (eds) Biogeochemistry of marine dissolved organic matter. Academic, San Diego, CA, pp 509-546

Boss E, Zaneveld JRV (2003) The effect of bottom substrate on inherent optical properties: evidence of biogeochemical processes. Limnol Oceanogr 48:346-354

Boyer EW, Hornberger GM, Bencala KE, McKnight DM (1997) Response characteristics of DOC flushing in an alpine catchment. Hydrol Process 11:1635-1647

Boyer EW, Hornberger GM, Bencala KE, McKnight DM (2000) Effects of asynchronous snowmelt on flushing of 
dissolved organic carbon: a mixing model approach. Hydrol Process 14:3291-3308

Butturini A, Alvarez M, Bernal S, Vazquez E, Sabater F (2008) Diversity and temporal sequences of forms of DOC and $\mathrm{NO}_{3}$-discharge responses in an intermittent stream: predictable or random succession? J Geophys Res 113:G03016. doi:1029/2008JG000721

Campbell JL, Hornbeck JW, Mitchell MJ, Adams MB, Castro MS, Driscoll CT, Kahl JS, Kochenderfer JN, Likens GE, Lynch JA, Murdoch PS, Nelson SJ, Shanley JB (2004) Input-output budgets of inorganic nitrogen for 24 forest watersheds in the northeastern United States: a review. Water Air Soil Pollut 151:373-396

Campbell JL, Mitchell MJ, Mayer B, Groffman PM, Christenson LM (2007) Mobility of nitrogen-15-labeled nitrate and sulfur-34-labeled sulfate during snowmelt. Soil Sci Soc Am J 71:1934-1944

Campbell JL, Rustad LE, Boyer EW, Christopher SF, Driscoll CT, Fernandez IJ, Groffman PM, Houle D, Kiekbusch J, Magill AH, Mitchell MJ, Ollinger SV (2009) Consequences of climate change for biogeochemical cycling in forests of northeastern North America. Can J For Res 39:264-284

Casciotti KL, Sigman DM, Galanter Hastings M, Böhlke JK, Hilkert A (2002) Measurement of the oxygen isotopic composition of nitrate in seawater and freshwater using the denitrifier method. Anal Chem 74:4905-4912

Coble PG (1996) Characterization of marine and terrestrial DOM in seawater using excitation-emission matrix spectroscopy. Mar Chem 51:325-346

Cory RM, McKnight DM (2005) Fluorescence spectroscopy reveals ubiquitous presence of reduced and oxidized quinone moiety in dissolved organic matter. Environ Sci Technol 39:8142-8149

Doctor DH, Kendall C, Sebestyen SD, Shanley JB, Ohte N, Boyer EW (2008) Carbon isotope fractionation of dissolved inorganic carbon (DIC) due to outgassing of carbon dioxide from a headwater stream. Hydrol Process 22:2410-2423

Downing BD, Boss E, Bergamaschi BA, Fleck JA, Lionberger MA, Ganju NK, Schoellhamer DH, Fujii R (2009) Quantifying fluxes and characterizing compositional changes of dissolved organic matter in aquatic systems in situ using combined acoustic and optical measurements. Limnol Oceanogr:Methods 7:119-131

Eckhardt BW, Moore TR (1990) Controls on dissolved organic carbon concentrations in Streams, Southern Québec. Can J Fish Aquat Sci 47:1537-1544

Ensign SH, Doyle MW (2006) Nutrient spiraling in streams and river networks. J Geophys Res 111:G04009. doi: 10.1029/2005JG000114

Fisher SG, Grimm NB, Martí E, Holmes RM, Jones JB (1998) Material spiraling in stream corridors: a telescoping ecosystem model. Ecosystems 1:19-34

Genereux D (1998) Quantifying uncertainty in tracer-based hydrograph separations. Water Resour Res 34:915-919

Glynn PD, Larsen MC, Greene EA, Buss HL, Clow DW, Hunt RJ, Mast MA, Murphy SF, Peters NE, Sebestyen SD, Shanley JB, Walker JF (2009) Selected achievements, science directions, and new opportunities for the WEBB small watershed research program. In: Webb RMT,
Semmens DJ (eds) Proceedings of the third interagency conference on Research in the watersheds: planning for an uncertain future: monitoring, integration, and adaptation. Scientific Investigations Report 2009-5049. US Geological Survey, Washington, DC

Harrison JA, Matson PA, Fendorf SE (2005) Effects of a diel oxygen cycle on nitrogen transformations and greenhouse gas emissions in a eutrophied subtropical stream. Aquat Sci 67:308-315

Hayhoe K, Wake CP, Huntington TG, Luo L, Schwartz MD, Sheffield J, Wood E, Anderson B, Bradbury J, DeGaetano A, Troy TJ, Wolfe D (2007) Past and future changes in climate and hydrological indicators in the US Northeast. Clim Dyn 28:381-407

Heffernan JB, Cohen MJ (2010) Direct and indirect coupling of primary production and diel nitrate dynamics in a subtropical spring-fed river. Limnol Oceanogr 55(2):677-688

Hodgkins GA, Dudley RW (2006a) Changes in late-winter snowpack depth, water equivalent, and density in Maine, 1926-2004. Hydrol Process 20:741-751

Hodgkins GA, Dudley RW (2006b) Changes in the timing of winter-spring streamflows in eastern North America, 1913-2002. Geophys Res Lett 33:L06402. doi:10.1029/ 2005GL025593

Hornberger GM, Bencala KE, McKnight DM (1994) Hydrological controls on dissolved organic carbon during snowmelt in the Snake River near Montezuma, Colorado. Biogeochemistry 25:147-165

Houlton BZ, Driscoll CT, Fahey TJ, Likens GE, Groffman PM, Bernhardt ES, Buso DC (2003) Nitrogen dynamics in icestorm damaged forest ecosystems: implications for nitrogen limitation theory. Ecosystems 6:431-443

Huntington TG, Hodgkins GA, Keim BD, Dudley RW (2004) Changes in the proportion of precipitation occurring as snow in Northeast (1949 to 2000). J Clim 17:2626-2636

Huntington TG, Richardson AD, McGuire KJ, Hayhoe K (2009) Climate and hydrological changes in the northeastern United States: recent trends and implications for forested and aquatic ecosystems. Can J For Res 39:199-212

Inamdar SP, O'Leary N, Mitchell MJ, Riley JT (2006) The impact of storm events on solute exports from a glaciated forested watershed in western New York, USA. Hydrol Process 20:3423-3439

Johnson KS, Colletti LJ (2002) In situ ultraviolet spectrophotometry for high resolution and long-term monitoring of nitrate, bromide and bisulfide in the ocean. Deep Sea Res I 49:1291-1305

Judd KE, Likens GE, Groffman PM (2007) High nitrate retention during winter in soils of the Hubbard Brook Experimental Forest. Ecosystems 10:217-225

Kendall KA, Shanley JB, McDonnell JJ (1999) A hydrometric and geochemical approach to test the transmissivity feedback hypothesis during snowmelt. J Hydrol 219: 188-205

Kirchner JW, Feng X, Neal C, Robson AJ (2004) The fine structure of water-quality dynamics: the (high-frequency) wave of the future. Hydrol Process 18:1353-1359

Lewis GP, Likens GE (2007) Changes in stream chemistry associated with insect defoliation in a Pennsylvania hemlock-hardwoods forest. For Ecol Manag 238:199-211 
McGlynn BL, McDonnell JJ (2003) Role of discrete landscape units in controlling dissolved organic carbon dynamics. Water Resour Res 39. doi:10.1029/2002WR001525

McGlynn BL, McDonnell JJ, Shanley JB, Kendall C (1999) Riparian zone flow path dynamics during snowmelt in a small headwater catchment. J Hydrol 222:75-92. doi: 10.1016/S0022-1694(99)00102-X

Mitchell MJ, Driscoll CT, Kahl JS, Likens GE, Murdoch PS, Pardo LH (1996) Climatic control of nitrate loss from forested watershed in the Northeastern United States. Environ Sci Technol 30:2609-2612

Mulholland PJ (2004) The importance of in-stream uptake for regulating stream concentrations and outputs of $\mathrm{N}$ and $\mathrm{P}$ from a forested watershed: evidence from long-term chemistry records for Walker Branch Watershed. Biogeochemistry 70:403-426. doi:10.1007/s10533-004-0364-y

Mulholland PJ, Kuenzler EJ (1979) Organic carbon export from upland and forested wetland watersheds. Limnol Oceanogr 24:960-966

Mulholland PJ, Thomas SA, Valett HM, Webster JR, Beaulieu $\mathrm{J}$ (2006) Effects of light on $\mathrm{NO}_{3}{ }^{-}$uptake in small forested streams: diurnal and day-to-day variations. J N Am Benthol Soc 25:583-595

Mulholland PJ, Roberts BJ, Hill WR, Smith JG (2009) Stream ecosystem responses to the 2007 spring freeze in the southeastern United States: unexpected effects of climate change. Glob Change Biol 15:1767-1776

Murdoch PS, Stoddard JL (1992) The role of nitrate in the acidification of streams in the Catskill Mountains of New York. Water Resour Res 28:2707-2720

Oczkowski AJ, Pellerin BA, Hunt CW, Wollheim WM, Vörösmarty CJ, Loder TC III (2006) The role of snowmelt and spring rainfall in inorganic nutrient fluxes from a large temperate watershed, the Androscoggin River basin (Maine and New Hampshire). Biogeochemistry 80:191-203

Ohno T (2002) Fluorescence inner-filtering correction for determining the humification index of dissolved organic matter. Environ Sci Technol 36:742-746

Ohte N, Sebestyen SD, Shanley JB, Doctor DH, Kendall C, Wankel SD, Boyer EW (2004) Tracing sources of nitrate in snowmelt runoff using a high-resolution isotopic technique. Geophys Res Lett 31:L21506. doi:10.1029/ 2004GL020908

Pacific VJ, Jencso KG, McGlynn BL (2010) Variable flushing mechanisms and landscape structure control stream DOC export during snowmelt in a set of nested catchments. Biogeochemistry 99:193-211

Pellerin BA, Downing BD, Kendall C, Dahlgren RA, Kraus TEC, Spencer RG, Bergamaschi BA (2009) Assessing the sources and magnitude of diurnal nitrate variability in the San Joaquin River (California) with an in situ optical nitrate sensor and dual nitrate isotopes. Freshw Biol 54: 376-387

Raymond PA, Hopkinson CS (2003) Ecosystem modulation of dissolved carbon age in a temperate marsh-dominated estuary. Ecosystems 6:694-705

Raymond PA, Saiers JA (2010) Event controlled DOC export from forested watersheds. Biogeochemistry. doi:10.1007/ s10533-010-9416-7

Riscassi AL, Scanlon TM (2009) Nitrate variability in hydrological flow paths for three mid-Appalachian forested watersheds following a large-scale defoliation. J Geophys Res 114:G02009. doi:10.1029/2008JG000860

Roberts BJ, Mulholland PJ (2007) In-stream biotic control on nutrient biogeochemistry in a forested stream, West Fork of Walker Branch. J Geophys Res Biogeosci 112:G04002. doi:10.1029/2007JG000422

Rusjan S, Mikoš M (2010) Seasonal variability of diurnal instream nitrate concentration oscillations under hydrologically stable conditions. Biogeochemistry 97:123-140

Sakamoto CM, Johnson KS, Coletti LJ (2009) Improved algorithm for the computation of nitrate concentrations in seawater using an in situ ultraviolet spectrophotometer. Limnol Oceanogr 7:132-143

Saraceno J, Pellerin BA, Downing BD, Boss E, Bachand PAM, Bergamaschi BA (2009) High frequency in situ optical measurements during a storm event: assessing relationships between dissolved organic matter, sediment concentrations and hydrologic processes. J Geophys Res Biogeosci 114:G00F09. doi:10.1029/2009JG000989

Scholefield D, Goff TL, Braven J, Ebdon L, Long T, Bulter M (2005) Concerted diurnal patterns in riverine nutrient concentrations and physical conditions. Sci Total Environ 344:201-210

Schuster PF, Shanley JB, Marvin-Dipasquale M, Reddy MM, Aiken GR, Roth DA, Taylor HE, Krabbenhoft DP, DeWild JF (2008) Mercury and organic carbon dynamics during runoff episodes from a Northeastern USA watershed. Water Air Soil Pollut 187:89-108

Sebestyen SD (2008) Coupled hydrological and biogeochemical processes that control stream nitrogen and dissolved organic carbon at the Sleepers River Research Watershed. PhD dissertation, State University of New York College of Environmental Science and Forestry, Syracuse, NY

Sebestyen SD, Boyer EW, Shanley JB, Kendall C, Doctor DH, Aiken GR, Ohte N (2008) Sources, transformations, and hydrological processes that control stream nitrate and dissolved organic matter concentrations during snowmelt in an upland forest. Water Resour Res 44:W12410. doi: 10.1029/2008WR006983

Sebestyen SD, Boyer EW, Shanley JB (2009) Responses of stream nitrate and DOC loadings to hydrologic forcing and climate change in an upland forest of the northeastern United States. J Geophys Res 114:G02002. doi: 10.1029/2008JG000778

Shanley JB, Chalmers A (1999) The effect of frozen soil on snowmelt runoff at Sleepers River, Vermont. Hydrol Process 13:1843-1857. doi:10.1002/(SICI)1099-1085

Shanley JB, Kendall C, Smith TE, Wolock DM, McDonnell JJ (2002) Controls on old and new water contributions to stream flow at some nested catchments in Vermont, USA. Hydrol Process 16:589-609. doi:10.1002/hyp.312

Shanley JB, Hjerdt KN, McDonnell JJ, Kendall C (2003) Shallow water table fluctuations in relation to soil penetration resistance. Ground Water 41:964-972

Spencer RGM, Pellerin BA, Bergamaschi BA, Downing BD, Kraus TEK, Smart DE, Dahlgren RD, Hernes PJ (2007a) Diurnal variability in riverine dissolved organic matter composition determined by in situ optical measurement in the San Joaquin River (California, USA). Hydrol Process 21:3181-3189 
Spencer RGM, Baker A, Ahad JME, Cowie GL, Ganeshram R, Upstill-Goddard RC, Uher G (2007b) Discriminatory classification of natural and anthropogenic waters in two U.K. estuaries. Sci Total Environ 373:305-323

Stream Solute Workshop (1990) Concepts and methods for assessing solute dynamics in stream ecosystems. J N Am Benthol Soc 9:95-119

van Verseveld WJ, McDonnell JJ, Lajtha K (2008) A mechanistic assessment of nutrient flushing at the catchment scale. J Hydrol 358:268-287
Weishaar JL, Aiken GR, Bergamaschi BA, Fram MS, Fujii R (2003) Evaluation of specific ultraviolet absorbance as an indicator of the chemical composition and reactivity of dissolved organic carbon. Environ Sci Technol 37:47024708

Wollheim WM, Vorosmarty CJ, Peterson BJ, Seitzinger SP, Hopkinson CS (2006) Relationship between river size and nutrient removal. Geophys Res Lett 33:L06410. doi: 10.1029/2006GL025845 